\title{
Compound Sentences in the Go'ét Speeches at the Réjéng Community's Penti Ceremony, Manggarai Regency
}

\author{
Stanislaus Hermaditoyo ${ }^{1}$, Melania Angelina Bahagia ${ }^{2}$ \\ Universitas Katolik Indonesia Santu Paulus Ruteng ${ }^{12}$
}

\{stennlyhermaditoyo@gmail.com $\left.{ }^{1}\right\}$

\begin{abstract}
This study aims to describe and analyze the form of compound sentences and the function of the go'ét speeches at the penti ceremony of the Réjéng community, Manggarai Regency. This type of qualitative research with data in the form of go'ét speech at the penti ceremony was obtained from several informants. The method used is the listening method and the interview method. The go'ét utterance is studied based on syntactic theory, especially compound sentences. Compound sentences are sentences that consist of two or more clauses. Between one clause with the other clauses are interconnected. Compound sentences consist of equivalent compound sentences, multilevel compound sentences, and mixed compound sentences. The go'ét utterance at the penti ceremony contains a compound sentence. The results showed that the utterance of go'ét-go'ét at the penti ceremony of the Réjéng community has a certain form and function. The form is a compound sentence equivalent to the density of 21 data, namely $1,4,6,13$, $14,15,16,17,18,20,22,23,24,25,26,27,31,32,33,34$, and 38 . There are 16 data of equivalent compound sentences, namely, data $2,5,7,8,9,10,11,12,21,28,29,30,35$, 36,37 , and 39 . The functions to convey economy, health, unity and brotherhood, the environment, hope, and gratitude. There are 6 datas on economic problems, 11 datas on health problems, 3 datas related to environmental issues, 10 datas related to the issue of hope, and 7 datas about gratitude.
\end{abstract}

Keywords: compound sentences, speech, go'ét, penti ceremony

\section{Introduction}

Syntax is a branch of linguistics that will examine lingual units in the form of words, phrases, clauses, sentences, to discourse (Khairah, 2015: 9). Sentence is a form of language that composes and pours one's thoughts openly to be communicated to others (Keraf, 2001: 34). Sentences contain a subject and a predicate, which are affixed with intonation or punctuation (Alwi, 2010: 39). Based on the form, sentences can be divided into two, namely single sentences and compound sentences. Compound sentences are sentences that consist of at least two basic sentences. The types of compound sentences in Indonesian are divided into 3 types, namely equivalent compound sentences, multilevel compound sentences, and mixed compound sentences (Yanti, 2016:86).

Manggarai language is a traditional language spoken by indigenous people from Manggarai Raya. The uniqueness of Manggarai in terms of socio-ethno linguistics is a cultural phenomenon that is rich and has great value. This can be seen in the Manggarai culture, there are many 
traditional ceremonies that use the go'ét speech. The go'ét utterance is used as a communication tool to convey the speaker's heart, one of which is the penti ceremony. This uniqueness is present in every go'ét utterance spoken in the ceremony. The go'ét utterance describes the reality of language as a forum for explaining the message that the speaker wants to convey. Whether in West, Central, or East Manggarai, the Manggarai language is a very strong regional identity. All Manggarai people feel one when this communication media is present as a mediator in every behaviour of social life accompanied by traditional procedures with local characteristics. As a result of the influence of changes and developments that occur at this time, the existence of regional languages including go'ét speech is threatened with extinction.

The Rejeng community of Bangka Lelak village, Lelak sub-district, Manggarai district, East Nusa Tenggara province, includes community groups who still adhere to old traditions, one of which is holding a penti ceremony, using go'et according to the context of its use. That is why go'et Manggarai has a very important function in instilling values into the younger generation of the Réjéng community group. Go'et Manggarai is closely related to Indonesian compound sentences. Compound sentences are sentences that consist of at least two basic sentences. There are 3 types of compound sentences in Indonesian, namely equivalent compound sentences, multilevel compound sentences, and mixed compound sentences (Yanti, 2016: 86). Go'et Manggarai also consists of two basic sentences. The words are arranged beautifully and attractively. These words always have a certain meaning or meaning and have been passed down from generation to generation (reweng dise ame, serong dise empo).

Penti Manggarai is a traditional New Year ceremony of the Manggarai people. Penti is an expression of gratitude to the Creator and offerings to the ancestors for blessings and graces in the past year and asking for blessings in the year to come. Penti is also a ritual effort to purify the village and its inhabitants from the influence of evil spirits so that they abstain from all sinful acts and do good things in the next life. The penti ritual is carried out jointly by the residents of the village centred in the mbaru gendang (traditional house) by offering sacrificial animals such as pigs or buffalo depending on the scale of needs and the number of guests invited (Institute for the Study of Archipelago Culture, 2018: 182-183).

Compound sentences are sentences that consist of at least two basic sentences. The types of compound sentences in Indonesian are divided into 3 types, namely equivalent compound sentences, multilevel compound sentences, and mixed compound sentences (Yanti, 2016:86). For example, in go'et penti“" kapu lami sangged gejur cama neho wua pau, ai itas lami hang ciwal haeng hang kawe. Compound equivalent sentences are sentences in which there are at least two single sentences and each of them can stand alone. For example, in go'et penti "Lebo kala, wua raci". The go'et consists of two single sentences that can stand alone.

A multilevel compound sentence is a sentence consisting of a core and not a core. The main part is called the main clause, and the non-core part is called the clause (Yanti, 2016: 87-88). For example, in go'ét penti "Waké celer nggerwa, saung bembang ngger eta". The results of the observations of researchers as the younger generation of Rejeng, Bangka Lelak Village, found several problems, namely: first, most of the younger generation of Rejeng in Bangka Lelak Village felt unfamiliar with the vocabulary contained in the go'ét speech. Actually, the go'ét speech is no stranger to hearing because it has been passed down from generation to generation by the ancestors, but because the ancestors passed it down in the form of speech (verbally) the younger generation now has difficulty learning the go'ét speech.

The difficulty of the younger generation in learning the go'ét speech is also caused by the younger generation being passive speakers of the regional language, which is influenced by globalization which makes it difficult for the younger generation to accept go'ét speech as a form of local wisdom that needs to be preserved. The younger generation also cannot accept 
themselves as part of a growing and developing community in their culture, so it is difficult for the younger generation to understand the meaning of the go'ét utterance.

Second, the low understanding of the young generation of Rejeng in Bangka Lelak village about compound sentences in the go'et speech at the penti ceremony in Rejeng. To understand compound sentences in go'et speech is very difficult for the younger generation because they feel foreign to the presence of go'ét, and also go'ét is formulated in the form of long sentences, so that the younger generation takes a long time to understand the compound sentences contained in go'et speech.

Third, the lack of understanding of the young generation of Rejeng about the function of go'ét at the penti ceremony in Rejeng. This problem was caused by the lack of attractiveness of the young generation of Réjéng in Bangka Lelak Village to participate in the rites of the penti ceremony in Rejeng. The author hopes that the younger generation of Rejeng, Bangka Lelak Village understands the compound sentences in the go'ét speech at the penti ceremony in Rejeng, the younger generation of Rejeng also understands the function of go'ét at the penti ceremony in Rejeng. The above is supported by the response of a young generation named Adrianus Wandrianto Purnama, age: 23 years.

According to him, penti is a traditional ceremony carried out by the local community to be grateful for the harvest that has been obtained. For the procession and the materials needed for the penti ceremony personally, he did not know. He also gave his response that go'et is a Manggarai proverb that functions as a means of communication with ancestral spirits. Brother Adrianus does not know the meaning of every go'et spoken during traditional ceremonies. He did not know what the function of the go'et utterance was at the penti ceremony. According to him, in the current era, penti is not important to carry out, the reason is because the implementation of the penti ceremony is very complicated and requires a lot of money. The purpose of the penti is to be grateful for the harvest. According to him, there will be no consequences if the penti is not implemented. He also said that in today's era go'ét does not need to be preserved because go'ét is no longer important. He does not know what go'et-go'et is said at the penti ceremony.

With this research, the young generation of Rejeng and the younger generation of Manggarai will get education that the go'et speech at the penti ceremony is important to learn, and the younger generation gains an understanding of the function of the go'et speech at the penti ceremony. And with this writing, it can also help the public in general to know and understand the Manggarai go'ét in the penti ceremony.

\section{Sentence}

Sentence is a form of language that pours one's thoughts to be communicated to others. Sentences consist of at least one clause. A clause is a group of words consisting of a subject and a predicate that has the potential to become a sentence. It is said to be a sentence if the clause is punctuation or final intonation. Sentences can be found both in written form and in spoken form. In written form, the first word begins with a capital letter and ends with a period (.), an exclamation point (!), and a question mark (?). In the form of oral speech, the spoken sentence is marked with final intonation.

Sentence is a form of language that composes and pours one's thoughts openly to be communicated to others (Keraf, 2001: 34). Sentences contain a subject and a predicate, which are affixed with intonation or punctuation (Alwi, 2010: 39). Example (1) Angelina has just bought a book. If the example is without a certain intonation or punctuation, then it is a clause. If the example above is affixed with intonation or punctuation, then the example is a sentence. 
If we add up and down intonation on the word "book", then a sentence is formed which is a news statement. In written form, this is realized by using a period punctuation mark (.). If the intonation goes up, or the punctuation is a question mark, then an interrogative sentence is formed. A clause can be a different sentence depending on the intonation or punctuation used (Alwi, 2010: 39). Sentence is the smallest unit of language that can express a complete thought, and can be realized in spoken and written form. Sentences in spoken form are marked with a loud and soft voice, and between pauses are ended with a finished tone. Sentences in written form begin with a capital letter and end with certain punctuation marks, namely a period punctuation mark (.), an exclamation mark (!), and a question mark (?) (Yanti, 2016: 75).

Examples of sentences, among others:

1. Jellin has not returned from his hometown.

2. Why is the proposal incomplete?

3. Go now!

The three examples above are called sentences because they have expressed a complete thought.

\section{Compound Sentence}

Compound sentences are sentences that consist of two or more clauses. Between one clause with the other clauses are interconnected. The relationship between clauses in a compound sentence is divided into three, namely: (1) coordinating relationship, (2) subordinated relationship, (3) co-subordinating relationship.

A compound sentence is a sentence that consists of more than one proposition so that it has at least two predicates that cannot be used as a unit. Because of this characteristic, compound sentences are always in the form of two or more clauses. If the relationship between one clause and another in a sentence states a coordinating relationship, then such a sentence is called an equivalent compound sentence (Alwi, 2010: 39-40). For example (5) Jellin leaves and her child starts crying. Example 5 above is an equivalent compound sentence because the relationship between Jellin's clause leaves and his child starts crying is equal. And also, the sentence has a coordinating relationship which is indicated by the conjunction and. If the relationship is subordinate, i.e. one is the main, while the other is a supplementary statement, then such a sentence is called a multilevel compound sentence.

Compound sentences are sentences that consist of at least two basic sentences. The types of compound sentences in Indonesian are divided into 3 types, namely equivalent compound sentences, multilevel compound sentences, and mixed compound sentences (Yanti, 2016:86). For example, in go'et penti (6) itas lami hang ciwal, haengs hang kawé”. Example 6 is an equivalent compound sentence because it consists of two clauses that have the same position. The sentence in example six is more precisely a compound sentence equivalent to a density because it does not use conjunctions but is represented by a comma (,).

\section{Types of Compound Sentences}

Compound sentences consist of equivalent compound sentences and multilevel compound sentences. Compound equivalent sentences are sentences in which there are at least two single sentences and each of them can stand alone (Yanti, 2016: 87-88). Compound equivalent sentences are grouped into four types, namely (a) compound equivalent sentences combined; (b) equivalent compound sentences of choice; (c) compound sentence equivalent sequence; (d) compound sentences equivalent to resistance. A compound sentence is a compound sentence that is a combination of two or more single sentences. This compound sentence is marked by 
the conjunction and, and, anyway (Yanti, 2016: 87). Equivalent compound sentences are sentences that consist of at least two single sentences and the relationship between these single sentences shows a selection relationship. This sentence is marked with a conjunction or (Yanti, 2016: 87).

A compound sentence equivalent to a sequence is an arrangement of sentences in which there are at least two single sentences and the relationship between these single sentences shows a sequence, state, or process relationship. This sentence is marked by a conjunction then, then, then, then (Yanti, 2016: 88). Compound sentences equivalent to resistance are sentence structures in which there are two single sentences, and the relationship between these single sentences shows the opposite relationship. This sentence is marked by the conjunction but, but, and while (Yanti, 2016: 88).

A multilevel compound sentence is a sentence consisting of a core and not a core. The main part is called the main clause, and the non-core part is called the clause. There are three characteristics to distinguish the main clause from the clause, namely, (1) degree; (2) connecting words; and (3) independence. The degree of the main clause has a higher level than the subordinate clause. Conjunctions used in compound sentences can be used to distinguish between main clauses and subordinate clauses. Independence is the main feature of the sentence. On the other hand, clauses cannot stand alone. The conjunctions that mark the clause are, although, even though, if then, because, because, before, after, even though, even though, so that, when, so, so that and so on (Yanti, 2016: 88-89).

Mixed compound sentences are a combination of equivalent compound sentences and multilevel compound sentences. The subordinated relationship shows a hierarchical relationship, which combines two or more clauses in stages, some of which function as main clauses and some that function as subordinate clauses. In a subordinated relationship, there are clauses that cannot stand alone, their existence depends on the main clause, so they cannot be separated from the chain of compound sentences. Therefore, the relationship is also called multilevel compound. Usually, the main clause is called an independent clause, while the subordinate clause is called a bound clause (Khairah, 2015: 183).

The co-subordination relationship is a relationship that resembles coordination, but each clause cannot stand alone as an independent clause because one clause is bound to another clause (Khairah, 2015: 190).

\section{Go'et}

Go'et is an expression or proverb in the Manggarai language or language style in the Manggarai language. Go'et is usually used in traditional events, and in these traditional events go'ét will be spoken according to the theme of the ongoing traditional event, for example a penti event or a harvest celebration. Go'et has many meanings and values that serve as role models for the life of the Manggarai community.

Go'et Manggarai is closely related to Indonesian compound sentences. Compound sentences are sentences that consist of at least two basic sentences. There are 3 types of compound sentences in Indonesian, namely equivalent compound sentences, multilevel compound sentences, and mixed compound sentences (Yanti et al 2016: 86). Go'ét Manggarai also consists of two basic sentences. The words are arranged beautifully and attractively. These words always have a certain meaning or meaning and have been passed down from generation to generation (reweng dise ame, serong dise empo). Go'et-go'et will be translated literally and in full

1. "itas lami hang ciwal, haéngs hang kawe".

Literally: We saw that we were eating lunch, we got some food. 
Whole: Obtaining food as a result of hard work.

2. "Lebo kala weri, wua raci po'ong"

Literally: Fertile betel leaf planting, planting areca nut.

Whole: Already getting results from an effort.

3. "Cing cama neho cing pumpkin, wela cama neho wéla ndesi".

Literally: Sprouts like pumpkin buds, blooms like cassava flowers.

Whole: In good health.

4. "Uwa haeng wulang, langkas haeng ntala".

Literally: Grows to the moon, and high to the stars.

Whole: Growing and healthy.

5. "Neka nepo leso, neka ringing tis".

Literally: Don't be tired from the sun, don't shiver

Whole: Always be healthy and stay strong.

\section{Research Methods}

Type of research used in this research is qualitative research. It is called a qualitative method because the data collected is the result of researching in natural conditions, and the analysis is more qualitative in nature. This understanding is based on the opinion of Sugiyono (2019: 18) who said that qualitative research methods are research methods based on the philosophy of post positivism, used to examine the condition of natural objects. Data obtained in this study, namely the form, function, utterance of go'ét go'ét at the penti ceremony of the Rejeng community, Manggarai district. Data obtained from interviews with several informants. Meanwhile, the data sources in this study were obtained from several informants who were considered to have mastered and understood the go'et-go'et speech at the Penti ceremony of the Rejeng community, Manggarai district.

The location of this research is Rejeng, Lelak District, Manggarai Regency with the research subject of the Réjéng community. The thing that underlies the researchers choosing the Rejeng area as the research location, because the penti ceremony has traditions and traditional speeches that are almost similar to the entire area in Lelak District, Manggarai Regency. Thus, the researcher only chose one area as the location of this research, namely the Réjéng area, Bangka Lelak village, Lelak sub-district. Data collection techniques in this study, using listening method, note-taking technique, documentation, and interview. In using the Listening Method, the researcher listened to the go'ét-go'ét utterances spoken by the informants during the interview and noted things that were relevant to the parts being studied with the help of stationery and notebooks. This understanding is based on the opinion of Sudaryanto (2016: 203) who said that it is called the listening method because it is in the form of listening: it is done by listening, namely listening to the use of language.

The main instrument in this research is the researcher himself. As a key instrument, researchers have several functions, namely determining the focus of research, selecting informants, and collecting data. Other instruments that are relevant to the focus and objectives of the research in order to collect more accurate data are interview guides, field notes, and digital cameras. 


\section{Results and Discussion}

The results of this study present data about the go'ét speech at the penti ceremony of the Rejeng community, Manggarai Regency, which will be analyzed according to the theory used by the researchers in this study. The data obtained from the results of in-depth interviews with three traditional leaders who have knowledge of the go'et speech at the penti ceremony in Rejeng.

\section{Research Results Data Compound Sentences}

According to Hermanus Nggau (Interview, April 14, 2021), the penti ceremony is a thanksgiving for the harvest that must be carried out by the Rejeng community group, Manggarai district. In the penti ceremony there is a go'et speech expressed by the spokesperson (ata torok). According to the researcher, the spokesperson played a very important role in the procession of the penti ceremony. The spokesperson (ata torok) in the penti ceremony is not just anyone, but really the person who controls the traditional conversation in the penti ceremony. Ata torok must understand the customs, and master the go'ét in the penti ceremony, because the go'et spoken is also not just any go'et.

The form of the go'ét speech at the penti ceremony expressed by Mr. Hermanus Nggau (74) when interviewed on April 14, 2021, Mr. Yohanes Pelas (58) April 17, 2021 and Mr. Fransiskus Ebat (78) when interviewed on April 30, 2021 contained compound sentences. According to the researcher, the form of compound sentences that appear in the said go'et utterances is that the sentences in the utterances consist of two or more single sentences which become one sentence when combined by connecting words. The description of the data in the form of compound sentences in the go'et speech at the penti ceremony is as follows:

1. Waké celer ngger wa, saung bémbang ngger éta.

2. Mori dasor ami uwa haéng wulang, agu langkas haéng ntala.

3. Nai ca anggit, tuka ca léléng.

4. Mori porong widang koé di'a, pati koé jari.

5. Porong ita hang ciwal lami agu haéng hang kawé.

6. Empo porong kémbus waé téku, mboas waé woang.

7. Néka koé woléng taé ami agu néka woléng curup.

8. Mori porong téla galang pé ang agu keté api oné.

9. Mori porong néka do ong oné golo agu néka asi oné béa.

10. Mori Emé nanang sarjanas dasor cai koé lé tanda agu émé nanang doktors porong cai koé lé golo.

11. Mori titong koé ata kop agu toing koé ata di'ad.

12. Mori wé 'ang koé gérak agu wancing koé nggaring.

13. Mori dasor néka nepo leso, néka ringing tis.

14. Mori porong cimang ného rimang cama rimang rana, kimpur neho kiwung cama ného kiwung tuak.

15. Empo dasor ami muku ca pu'u toé woléng curup, téu ca ambo toé woléng lako.

16. Ipung ca tiwu neka woleng impung, nakéng ca waé neéka woléng ka 'éng.

17. Mori porong ami cama léwang ngger pé 'ang, cama po'é ngger oné.

18. Lebo kala weri, wua raci po'ong.

19. Tewar wua agu recak wéla.

20. Pé 'ang-pé 'ang wéla pé 'ang-pé 'ang wécak, sili-sili cing sili-sili wisi.

21. Mori porong ami beka cama laing sili tacik agu cama ntala éta awang.

22. Mori porong néka behas ného kena, néka koas ného kota. 
23. Mori porong ami régés lima léké, tawa lima gantang.

24. Mori téi tewar koé wua, téi wécak koe wéla.

25. Empo dasor néka nangki kolé tai, néka itang kolé diang.

26. Mori porong Ngger lau darum, ngger céé becur.

27. Mori porong ngger laus hontas, ngger céés mbéhok.

28. Emo ami sala lampa agu cé'ot wéjong.

29. Ami toe ngoeng retak cepa agu pora raci.

30. Néka hamar oné anak agu néka dédam oné wéla.

31. Na'a cekeng manga, curu cekeng weru.

32. Na'a ntaung manga, werus ntaung weru.

33. Mbaru baté ka'éng, agu uma baté duat.

34. Néka cumang dungka, néka pangga cala.

35. Natas baté labar, agu compang tara dari.

36. Ata sor moso agu ata kawe mbaek.

37. Porong néka tewi weki agu néka kotok longor.

38. Porong nggari lau ténggéng, nggari cé 'é mbehok

39. Porong doro koé nos, agu roi koé ongkas.

40. Mori ami kut wali sanggén di'ad ata poli itad

41. Reca rangga wali ntaung.

42. Célu cekeng wali ntaung

43. Néka conga bail bokak rantang kepu tengu.

44. Néka langgar wancang, agu néka larong ri’i

Compound Sentence Forms and Go'ét-Go'ét Speech Functions at the Rejeng Community Penti Ceremony, Manggarai Regency Of the 44 data obtained, 42 are used and will be analyzed, and there are 2 that are not analyzed because these data are not used in this paper, namely data (43 and 44) for certain reasons. The analyzed data has been validated by the translation validator on behalf of Mr. Fransiskus Ebat. Not all of them are shown in this article. Attached data.

Table 1. Data 1

\begin{tabular}{|l|l|}
\hline Data & "Waké celer ngger wa, saung bémbang ngger éta". \\
\hline Literal Translation & $\begin{array}{l}\text { Waké: Akar, celer: tunggang, ngger wa: ke bawah, saung: daun, } \\
\text { bémbang: rimbun, ngger éta: ke atas. }\end{array}$ \\
\hline $\begin{array}{l}\text { Contextual } \\
\text { Translation }\end{array}$ & strong roots, lush leaves and ask for health and long life \\
\hline Speech Function & $\begin{array}{l}\text { The utterance is a speech related to the theme of health, so the utterance } \\
\text { functions to ask the local community to have a long life. People also } \\
\text { realize that their lives are likened to a tree where the thick leaves on the } \\
\text { tree hang from its strong roots. Likewise, human life that health depends } \\
\text { on the way of human life itself. }\end{array}$ \\
\hline
\end{tabular}

Data above is a sentence that is classified as an equivalent compound sentence because it consists of two clauses that have the same position and can stand alone. The sentence in data 1 is more precisely a compound sentence equivalent to a density because of the omission of the conjunction (agu) which means (and), also represented by a comma (,) after the first clause. 
Table 2. Data 2

\begin{tabular}{|l|l|}
\hline Data & Mori dasor uwa haéng wulang, agu langkas haéng ntala. \\
\hline Literal Translation & $\begin{array}{l}\text { Mori: Tuhan, dasor: semoga, } \text { uwa: bertumbuh, haéng: sampai, wulang: } \\
\text { bulan, agu: dan, langkas: tinggi, haéng: sampai, ntala: bintang. }\end{array}$ \\
\hline $\begin{array}{l}\text { Contextual } \\
\text { Translation }\end{array}$ & $\begin{array}{l}\text { A request for good health and hope for a long life for the local } \\
\text { community. }\end{array}$ \\
\hline Speech Function & $\begin{array}{l}\text { The problem contained in the sentence is the issue of hope to stay } \\
\text { healthy and what is desired to be achieved. So the utterance functions } \\
\text { to ask people to stay in good health, so that what they want can be done } \\
\text { and can be achieved properly }\end{array}$ \\
\hline
\end{tabular}

Data 2 above is an equivalent compound sentence because the sentence consists of two clauses that have the same position, namely the first clause Mori dasor uwa haéng wulang, the second clause Langkas haéng ntala. The sentence in the go'ét speech in data 2 is also connected with a conjunction $(a g u)$ which means (and).

Table 3. Data 3

\begin{tabular}{|l|l|}
\hline Data & "Nai ca anggit tuka ca léléng" \\
\hline Literal Translation & Nai: Hati, ca: satu, anggit: ikatan, tuka: perut, ca: satu, léléng: bersatu. \\
\hline $\begin{array}{l}\text { Contextual } \\
\text { Translation }\end{array}$ & $\begin{array}{l}\text { A request for unity in common life both in the form of actions and words. } \\
\text { Or in other words united in spirit and taste. }\end{array}$ \\
\hline Speech Function & $\begin{array}{l}\text { The speech is related to the issue of unity and harmony in dealing with } \\
\text { the general problems of the local community. So the speech is spoken } \\
\text { because of the hope that community members remain in harmony in } \\
\text { dealing with situations that are happening in society. }\end{array}$ \\
\hline
\end{tabular}

Data above does not include compound sentences. It is said so because based on its understanding, a compound sentence is a combination of clauses, not phrases. In this speech, it is not a combination of words that are categorized as clauses. The combination of these words is a collection of phrases, namely the first phrase is Nai ca anggit. The second phrase is tuka ca leleng.

Table 4. Data 4

\begin{tabular}{|l|l|}
\hline Data & Mori porong widang koé di'a, pati koé jari. \\
\hline Literal Translation & $\begin{array}{l}\text { Mori: Tuhan, porong: semoga, widang: tolonglah, di'a: yang baik, pati: } \\
\text { berbagilah, jari: yang jadi }\end{array}$ \\
\hline $\begin{array}{l}\text { Contextual } \\
\text { Translation }\end{array}$ & $\begin{array}{l}\text { A request to be given good things by God, especially for the prosperity of } \\
\text { life. }\end{array}$ \\
\hline Speech Function & $\begin{array}{l}\text { The problem contained in the go'ét speech is related to hope, so the speech } \\
\text { serves to convey hope which contains hope that the community will be } \\
\text { bestowed with good things by God Almighty as well as asking for } \\
\text { sustenance from God the Creator }\end{array}$ \\
\hline
\end{tabular}


The speech in data 4 above is an equivalent compound sentence because it consists of two clauses that have the same position. The sentence in data (4) is more precisely a compound sentence equivalent to a density because it does not use conjunctions / there is an omission of the conjunction agu (and), it is represented by a comma (,) after the first clause, namely Mori porong widang koé di'a.

Table 5. Data 6

\begin{tabular}{|l|l|}
\hline Data & Empo porong kémbus waé téku, mboas waé woang. \\
\hline Literal Translation & $\begin{array}{l}\text { Empo: leluhur, porong: semoga, kémbus: besar debit, waé: air, téku: } \\
\text { timbah, mboas: deras, waé: air, woang: pancuran. }\end{array}$ \\
\hline $\begin{array}{l}\text { Contextual } \\
\text { Translatio }\end{array}$ & $\begin{array}{l}\text { The request to live like a big and swift spring that can provide prosperity } \\
\text { and prosperity for the life of the local community. }\end{array}$ \\
\hline Speech Function & $\begin{array}{l}\text { The speech is related to the environment, so the speech serves to convey } \\
\text { hope for a clean, beautiful environment, hopefully living with the } \\
\text { availability of abundant drinking water for the life of living things every } \\
\text { day }\end{array}$ \\
\hline
\end{tabular}

Data above is an equivalent compound sentence because it consists of two clauses that have the same position, and is more precisely a compound sentence equivalent to a density because it does not use conjunctions or there is an omission of the conjunction agu (and), and is represented by a comma (, ) after the first clause, namely Empo porong kémbus waé téku.

Table 6. Data 7

\begin{tabular}{|l|l|}
\hline Data & Néka woléng taé ami agu néka woléng curup. \\
\hline Literal Translation & $\begin{array}{l}\text { Néka: Jangan, woléng: pisah, taé: kata, ami: kami, agu: dan, néka: } \\
\text { jangan, woleng: pisah, curup: bicara. }\end{array}$ \\
\hline $\begin{array}{l}\text { Contextual } \\
\text { Translation }\end{array}$ & Request that the local community unite in making a joint decision. \\
\hline Speech Function & $\begin{array}{l}\text { The problems contained in the go'ét speech are related to a } \\
\text { harmonious and peaceful life, so the speech serves to convey a request } \\
\text { that contains the hope that the local community will live in harmony } \\
\text { and be kept away from misunderstandings/disagreements. }\end{array}$ \\
\hline
\end{tabular}

Data above is an equivalent compound sentence because it consists of two clauses that have the same position and are connected by the conjunction $a g u$ (and) as a marker that the sentence is a compound sentence.

Table 7. Data 8

\begin{tabular}{|l|l|}
\hline Data & Mori porong téla galang pé 'ang pé 'ang agu keté api oné. \\
\hline $\begin{array}{l}\text { Literal } \\
\text { Translation }\end{array}$ & $\begin{array}{l}\text { Mori: Tuhan, porong: semoga, téla: terbuka, galang palungan, } \\
\text { péang: luar, agu: dan, keté: nyala, api: api, oné: dalam. }\end{array}$ \\
\hline $\begin{array}{l}\text { Contextual } \\
\text { Translation }\end{array}$ & Pray to God for sustenance. \\
\hline
\end{tabular}




\begin{tabular}{|l|l|}
\hline Speech Function & $\begin{array}{l}\text { The problem contained in the speech is an economic problem, } \\
\text { so the speech serves to convey a request that contains the hope } \\
\text { that the economic conditions in the coming year and season } \\
\text { from the local community will be more stable than the previous } \\
\text { year and season. }\end{array}$ \\
\hline
\end{tabular}

Data above is an equivalent compound sentence because it consists of two clauses that have the same position. The sentence is also connected with a conjunction (agu) which means (and) as one of the characteristics of a compound sentence.

Table 8 . Data 13

\begin{tabular}{|l|l|}
\hline Data & Mori dasor néka nepo leso, néka ringing tis. \\
\hline Literal Translation & $\begin{array}{l}\text { Mori: Tuhan, dasor: semoga, néka: jangan, nepo: lemah leso: hari, } \\
\text { néka: jangan, ringing: menggigil, tis: tetes. }\end{array}$ \\
\hline $\begin{array}{l}\text { Contextual } \\
\text { Translation }\end{array}$ & $\begin{array}{l}\text { Request that the village community be healthy and strong so that they } \\
\text { can carry out their daily activities properly. }\end{array}$ \\
\hline Speech Function & $\begin{array}{l}\text { The speech in the data above is related to health issues, so the speech } \\
\text { serves to convey a request that contains hope that the community will } \\
\text { remain healthy and strong. }\end{array}$ \\
\hline
\end{tabular}

The speech in data 13 above is an equivalent compound sentence because it consists of two clauses that have the same position. The sentence is more precisely a compound sentence equivalent to a density because it does not use conjunctions, but is represented by a comma (,) after the first clause, namely Mori dasor néka nepo leso.

Table 9. Data 18

\begin{tabular}{|l|l|}
\hline Data & lebo kala weri, wua raci po'ong \\
\hline Literal Translation & $\begin{array}{l}\text { Lebo: Lebat, kala: daun sirih, weri: tanam, wua: buah, raci: pinang, } \\
\text { po'ong: tanam }\end{array}$ \\
\hline $\begin{array}{l}\text { Contextual } \\
\text { Translation }\end{array}$ & $\begin{array}{l}\text { Request that what the villagers are trying to do is successful and } \\
\text { successful. }\end{array}$ \\
\hline Speech Function & $\begin{array}{l}\text { The problem contained in the speech is an economic problem. So the } \\
\text { speech serves to convey a request so that the economic condition of } \\
\text { the community improves. }\end{array}$ \\
\hline
\end{tabular}

Data above includes equivalent compound sentences because the relationship between the words in the first clause is parallel to the second clause. lebo kala weri, wua raci po'ong. The word lebo is parallel to the word wua, the word kala is parallel to the word raci, the word weri is parallel to the word $p o^{\prime}$ ong. The sentence is more precisely a compound sentence equivalent to a density because it does not use conjunctions, but is represented by a comma (,) after the first clause. 
Table 10. Data 23

\begin{tabular}{|l|l|}
\hline Data & Mori porong ami régés lima léké, tawa lima gantang. \\
\hline Literal Translation & $\begin{array}{l}\text { Mori: Tuhan, porong: semoga, ami: ami, régés: terbahak-bahak, } \\
\text { lima: lima, léké: tempurung kelapa, tawa: ketawa, lima: lima, } \\
\text { gantang: dulang. }\end{array}$ \\
\hline $\begin{array}{l}\text { Contextual } \\
\text { Translation }\end{array}$ & Request that the village community rejoice. \\
\hline Speech Function & $\begin{array}{l}\text { The problem in the speech is the issue of joy. So the utterance serves } \\
\text { to convey gratitude for the joys of joy faced by the local community } \\
\text { and plead for the community to be kept away from grief. }\end{array}$ \\
\hline
\end{tabular}

Date above is an equivalent compound sentence because it consists of two clauses that have the same position. The utterance is more precisely a compound sentence equivalent to a density because it does not use conjunctions, but is represented by a comma (,) after the first clause.

Table 11. Data 31

\begin{tabular}{|l|l|}
\hline Data & Kut Na'a lami cekeng manga, curu cekeng weru. \\
\hline Literal Translation & $\begin{array}{l}\text { Kut: Supaya, Na'a: simpan, lami: oleh kami, cekeng: musim, manga: } \\
\text { lama, curu: jemput, cekeng: musim, weru: baru. }\end{array}$ \\
\hline $\begin{array}{l}\text { Contextual } \\
\text { Translation }\end{array}$ & Season change. \\
\hline Speech Function & $\begin{array}{l}\text { The problem contained in the speech is the issue of gratitude and hope. } \\
\text { So the utterance serves to convey gratitude to God and ancestors for } \\
\text { having passed the long season well and at the same time conveying a wish } \\
\text { that contains hope so that the coming season can be faced well as well }\end{array}$ \\
\hline
\end{tabular}

Data (31) "includes equivalent compound sentences because it consists of two clauses that have the same position. The utterance is more precisely a compound sentence equivalent to a density because it does not use conjunctions, but is represented by a comma (,) after the first clause.

Table 11. Data 33

\begin{tabular}{|l|l|}
\hline Data & Mbaru baté ka'éng, agu uma baté duat. \\
\hline Literal Translation & $\begin{array}{l}\text { Mbaru: Rumah, bate: tempat, ka'éng: tinggal, agu: dan uma: kebun, } \\
\text { bate: tempat, duat: bekerja. }\end{array}$ \\
\hline $\begin{array}{l}\text { Contextual } \\
\text { Translation }\end{array}$ & Place to live and work. \\
\hline Speech Function & $\begin{array}{l}\text { The problem contained in the speech is an environmental issue. So the } \\
\text { utterance serves to convey gratitude to God and ancestors for having } \\
\text { been awarded a house as a proper place to live and a garden as a place } \\
\text { to earn a living. }\end{array}$ \\
\hline
\end{tabular}


Data above includes equivalent compound sentences and is more precisely a compound sentence equivalent to density because there is an omission of conjunctions so that they do not use conjunctions, but are represented by a comma (,) after the first clause. The form of the sentence in the go'ét speech at the penti ceremony of the Rejeng community obtained from the research results by the researcher will describe its form in terms of linguistics, namely the form of compound sentences found in the go'ét speech at the penti ceremony of the Rejeng community.

The researcher chose to analyze the form of compound sentences in the go'ét speech at the penti ceremony, because based on the data obtained, the go'ét speech at the penti ceremony of the Rejeng community contains a lot of compound sentences. A compound sentence is a sentence that consists of two or more clauses. Compound Equivalent Sentences are sentences in which there are at least two single sentences and each of them can stand alone. Of the 42 data that have been analyzed, there are 16 data including equivalent compound sentences, namely, $2,5,7,8,9,10,11,12,21,28,29,30,35,36,37$, and 39. 21 data included in compound sentences with the equivalent of density, namely, 1, 4, 6, 13, 14, 15, 16, 17, 18, 20, 22, 23, 24, $25,26,27,31,32,33,34,38$. There are 5 data that do not include compound sentences, namely, data $3,19,40,41,42$.

The analyzed data serves to convey economic issues, health, unity and brotherhood, the environment, hope and gratitude. There are (6) data on economic issues, namely data 8, 18, 19, 24, 26, and 38. There are 11 data on health issues, namely data 1, 13, 14, 20, 21, 27, 29, 30, 34, 37 , and 41 . There are 5 data relating to issues of unity and brotherhood, ie data $3,7,15,16$, and 17. There are 3 data related to environmental issues, namely data 6,33 , and 39 . There are 10 data related to the issue of expectations, namely data 2, 4, 5, 9, 10, 11, 12, 22, 25, 28. And there are 7 data about thanksgiving, namely data $23,31,32,35,36,40$, and 42 . The data above shows that in the Manggarai tradition, there are goets which have different functions, meanings and forms.

\section{Conclusion}

Based on the analysis and discussion, it can be concluded that the go'ét speech at the penti ceremony is a form of using the Manggarai language. The go'ét speech at the penti ceremony aims to convey the speaker's heart. The go'ét-go'ét speech at the penti ceremony of the Réjéng community, Manggarai Regency contains compound sentence forms. The form of compound sentences that appear in the said go'ét utterance, namely the sentence in the utterance consists of two or more single sentences that become one. Every go'ét-go'ét speech at the penti ceremony of the Rejeng community, Manggarai Regency contains a certain function. The function of the speech can be obtained from the problems contained in the speech.

The data that has been analysed serves to convey economic issues, health, unity and brotherhood, the environment, hope and gratitude. There are (6) data on economic issues, namely data $8,18,19,24,26$, and 38 . There are 11 data on health issues, namely data $1,13,14$, $20,21,27,29,30,34,37$, and 41 . There are 5 data related to the issue of unity and brotherhood, ie data $3,7,15,16$, and 17 . There are 3 data related to environmental issues, namely data 6,33 , and 39 There are 10 data related to the issue of hope, namely data 2, 4, 5, 9, 10, 11, 12, 22, 25, 28. There are 7 data on gratitude, namely data $23,31,32,35,36,40$, and 42 .

The go'ét speech at the penti ceremony contains compound sentences, so the researchers discovered that compound sentences are not only obtained from Indonesian, but compound 
sentences can also be found in the Manggarai language, especially in the go'et speech at the penti ceremony of the Rejeng community. The dominant compound sentences found in this study are compound sentences with a density equivalent, namely from 42 data there are 21 data including compound sentences with dense equivalent $(1,4,6,13,14,15,16,17,18,20,22,23)$. , 24, 25, 26, 27, 31, 32, 33, 34, and 38).

\section{References}

[1] Alwi, Hasan. 2010. Tata Bahasa Baku Bahasa Indonesia. Jakarta: Pusat Bahasa dan Balai Pustaka.

[2] Dagur, Antony. B. 2008. Budaya Daerah dalam Konteks Komunikasi. Ende: Nusa Indah.

[3] Ebat, S. Robert, dan Ebat, Fransiskus. 2018. Kamus Bahasa:Manggarai-Indonesia, IndonesiaManggarai. Bogor: Mardi Yuana.

[4] Janggur, Petrus. 2008. Butir-Butir Adat Manggari buku 2, Ruteng: Artha Gracia.

[5] Janggur, Petrus. 2010. Butir-Butir Adat Manggari, Ruteng: Yayasan Siri Bongkok.

[6] Keraf, Gorys. 2001. Komposisi, Ende: Nusa Indah,

[7] Khairah M, dan Ridwan S. 2015. Sintaksis:Memahami Satuan Kalimat Perspektif Fungsi, Jakarta: Bumi Aksara.

[8] Lembaga Pengkajian Kebudayaan Nusantara. 2019. Ensiklopedia Manggarai. Bogor: Cileungsi.

[9] Purwandari, Retno. 2015. Buku Pintar Bahasa Indonesia. Yogyakarta: Istana Media

[10] Sudaryanto. 2016. Metode dan Aneka Teknik Analisis Bahasa: Pengantar Penelitian Wahana Kebudayaan secara Linguistis. Yogyakarta:Universitas Sanata Dharma Anggota APPTI 